\title{
INTEGRATION OF POLITICAL FACTS AND WAYANG STORIES IN MODERN INDONESIAN NOVELS
}

\author{
Anwar Efendi \\ Universitas Negeri Yogyakarta, Indonesia \\ anwar@uny.ac.id
}

\section{Burhan Nurgiyantoro \\ Universitas Negeri Yogyakarta, Indonesia \\ burhan@uny.ac.id}

\begin{abstract}
The presence of political events and wayang stories integrated into modern Indonesian novels is an interesting fact. Political events are facts and knowledge, while wayang stories and novels are fiction and imagination. These two things can be brought together coherently in modern Indonesian novels. Political events are used as historical settings, while wayang stories are used as references for character development, plot, and cultural references. This study aims to describe the way the authors reveal political events in Indonesian history by using wayang as a narrative medium. This article focuses on two novels, namely Amba by Laksmi Pamuntjak and Pulang by Leila S. Chudori. The two novels have one thing in common, both of which highlight the political event of the 30 September Movement of Indonesian Communist Party (PKI) in 1965, which is usually referred to as G30S/PKI, and the political life under the New Order regime which was integrated intensively with wayang stories. From the point of view of Indonesian political history, the two novels raised the issue of the political policies of the New Order government to dissolve the Indonesian Communist Party and communism. The policy is considered to be imposed also upon people who were actually not involved, were not sympathizers, and did not even know what really happened. From the standpoint of wayang culture, wayang characters are referred to in naming the novel's characters. In Amba, the plot refers to the wayang story about the love triangle between Amba, Salwa, and Bhisma. In fact, Amba, whose name is the title of the novel, is also the name of a wayang character. In Pulang, Dimas considers the wayang characters Bima and Ekalaya as a metaphor for himself. Bima is considered as a metaphor for himself in matters of love, while Ekalaya is a metaphor for the love of the country even though he is exiled. Dimas, who lives as an exile abroad, is a victim of the purge of communism by the government.
\end{abstract}




\section{Keywords}

political setting, wayang story, G30S/PKI, exile, modern Indonesian novels

\section{About the Authors}

Anwar Efendi is an associate professor of modern Indonesian literature at the Department of Indonesian Language and Literature, Faculty of Languages and Arts, Universitas Negeri Yogyakarta. His research interests are literature and religiosity (prophetic), comparative literature, and literary learning.

Burhan Nurgiyantoro holds a $\mathrm{PhD}$ in literature and is a professor of modern Indonesian literature at the Department of Indonesian Language and Literature, Faculty of Languages and Arts Universitas Negeri Yogyakarta. His research interests are children's literature, fiction study, evaluation of literary learning, and stylistics. 


\section{INTRODUCTION}

Political and literary issues have long been debated since Plato, and they are still considered interesting points for discussion to this day. One must note that politics and literature are two areas that are not the same because their goals are different (Eilders and Nitsch 1564). The term "politics and literature" can refer to several definitions, for example, "politics in literature" and "literary politics" (Whitebrook 55). The term "politics in literature" refers to the inclusion of political aspects in the literature. The term "literary politics" is one of the forms of literary criticism approaches, for example, the postcolonial approach, cultural studies, feminism, and others (Sayed 251; Rancière 10).

Political events as concrete manifestations of ideology can be found in fiction. This becomes the object of the study of "politics in literature." This approach typically examines the emergence of political content, the tendency of authors' political attitudes, or political contexts in a literary text (Whitebrook 55; Eilders and Nitsch 1564). Furthermore, Whitebrook (57-58) argues that it is fairly common for people to study politics through literature rather than through nonfictional political books. In his book, Politics and Literature at the Turn of the Millennium, Michael Keren suggests that political scientists should utilize literary texts to teach political theory (Sayed 252). Literary texts that emphasize the importance style and technique can help make discussions of political theory more compelling. Therefore, if one can see how politics and fiction mutually influence each other, one can arrive at a better understanding of the relationshiop between these two seemingly different fields.

In a short essay entitled "Does Fiction Have the Power to Sway Politics?" Hamid (2015) argues that fiction can influence politics. All works of fiction are political. Fiction writers who claim that their writings are not political are simply trying to separate themselves from the politics their writings develop. Writing stories is an inherently political act; fiction can say publicly what might otherwise appear unsayable.

In the context of a creative process, historical and political facts are social realities that can inspire and influence creative texts (literary works). Since authors are members of society, their opinions and perspectives on important political and social issues will be reflected in their works. In this sense, literary works can be considered as evaluative interpretations of the author's milieu through the creative use of language. On this note, a literary work can be a rediscovery of strengths and weaknesses in the past, successes in the present, or failure in facing life in the future (Sayuti 34). 
One of the many political events that have been featured in Indonesian literature is the 30 September Movement of Indonesian Communist Party (PKI) in 1965 (known as G3oS/PKI). This event was the climax of a political rupture in Indonesian society which was sharply divided into pro-communist and anti-communist sides. This incident had an impact on fundamental changing of Indonesian politics (Said xii).

A historical or political fact, such as the G30S/PKI incident, can enter into a fictional story, and even become an important content. However, once entered into fiction, history and politics must submit to a fiction system. Historical data used in fiction becomes part of the fiction system and is no longer part of the system of reality (Junus 51).

During the New Order era (1968-1998), the understanding and interpretation of historical materials, especially the G30S/PKI events, was very much dominated by the state's cognitive mastery of society. Therefore, Indonesian authors have their own expression techniques to raise the G3oS/PKI events in their creation of literary works. One expression technique chosen is to utilize wayang. Wayang is one of the traditional cultures that is very attached to Indonesian society, especially in Java and Bali.

Wayang elements can be adapted in various works of art, including literary works. Moreover, wayang can be medium in spreading views and criticisms of contemporary Indonesian culture, politics, and society (Downes 108). Puppet stories, characters, and motives have been used for various purposes, including avoiding censorship and criticizing government ideology (Pausacker 217; Basuki 8o).

This means that not only does the integration of political aspects become a point of interest for this study, but also the transformation of wayang stories in modern Indonesian novels. Political events are historical accounts; fiction is imagination (Janoory 188); is it possible for these to meet? The problem raised in this paper is how to integrate the two elements: political events with the story and wayang symbols in the novel.

\section{THE 30 SEPTEMBER MOVEMENT}

The dramatic events that occurred in 1965 marked a turning point in the history of the Indonesian nation. On the morning of 1 October 1965, a group of left-wing military officers calling themselves the 30 September Movement kidnapped and 
killed several right-wing generals (Eickhof 453). Left-wing troops raided the homes of seven anti-communist generals, including Army Commander General Ahmad Yani and Defense Minister General A. H. Nasution. Three people were shot on the spot and three people were transported to an air force base in the south of Jakarta where they were killed. Nasution was able to escape, but his daughter was killed. An adjutant of Nasution was also a victim in the incident.

The leader of the 30 September Movement action was Lt. Col. Untung, Commander of President Sukarno's Guard. Untung stated that he had acted to prevent a military coup by the "Council of Generals" and that the power of the state then rested with the Revolutionary Council. Regardless of whether the movement had originally intended to assassinate the generals, their actions after dawn on 1 October represented a lack of planning. The Revolutionary Council seems to be formed in a hurry without proper coordination. The coup d'état did not take serious action to seize key points to control Jakarta or to destroy opposing forces. As a result, the Army's Strategic Reserves, headed by Lieutenant General Suharto, were able to take the initiative and end the coup in a short time (Cribb 223).

This incident occurred as a result of the escalation of political conflict in Indonesia which was heating up between the three (triangle) forces, namely the Indonesian Communist Party (PKI), President Sukarno, and the Army (Said xi). There was a conflict of interest in power, authority, and influence between the three forces. They wanted to bring each other down. These three forces were formed through crystallization during the Guided Democracy period. Sukarno's actions of arresting and detaining his political opponents were seen as benefitting the PKI (Anwar 349).

When the G3oS / PKI rebellion erupted (September-October 1965), which was marked by the murder of the generals, General Suharto appeared as a savior of the situation. The people, who had been intimidated by the communist forces for years, now supported the anti-communist Suharto. Prior to the G3oS/PKI rebellion, communists aggressively intimidated people they considered their political opponents. After the G30S/PKI rebellion, it was the communists, sympathizers, and their families who became targets of intimidation and violence. In subsequent developments, history records that Suharto transformed into an absolute ruler for 32 years with the full rule of the New Order regime.

After the event of 1965, General Suharto then became Indonesia's second president to hold power for more than thirty years until his fall as a result of the reform movement in 1998. Over three decades, Suharto gained a reputation as a strongman in Southeast Asia, having endured political maneuvers by using authoritarian measures to maintain power. The long life of the New Order regime 
was also partly due to acts of violence sanctioned by the state. In essence, the foundations of Suharto's New Order regime were built on the lives of those who were imprisoned, tortured, and killed after the event of 30 September 1965 (Leong 733).

Apart from the controversy over who is considered guilty and should be responsible for the G30S/PKI incident, there are several important things that should be noted, namely: kidnapping and torture, arrest and imprisonment, discriminatory treatment, and revocation of citizenship status. First, the kidnapping, torture, and murder of people considered to be members and sympathizers of the Indonesian Communist Party. It was estimated that 500,000 people accused of being members of the Indonesian Communist Party (PKI) were killed during this period (Cribb 225; Roosa 117). Second, the arrest and imprisonment of PKI members and sympathizers was undertaken without going through an honest and open justice process. Tens of thousands of people were imprisoned without trial (Amnesty International). Third, there was treatment discrimination of PKI members and sympathizers by limiting their basic rights, such as freedom of activity and obtaining employment in the government. This discrimination is also imposed on their children and grandchildren, by giving status to their identity as part of a prohibited organization (OT). Fourth, the revocation of citizenship status for people who are considered PKI members and sympathizers who are abroad. Thousands of Indonesians who studied abroad in 1965 became stateless exiles when Suharto's New Order canceled and revoked their passports.

Suharto fell in 1998 through the reform movement. The years after 1998 brought significant signs of change. The democratic government brought a new atmosphere in responding to and understanding the G3oS/PKI events. This was preceded by President Abdurrahman Wahid (Gus Dur)'s open apology to members and sympathizers of the Indonesian Communist Party who were victims of the murder. In 2004, the Indonesian parliament passed a law on truth and a reconciliation commission. Gus Dur also disbanded the National Security and Stability Coordinating Board and the Social and Political Service, which during the New Order discriminated against people who were considered PKI members and sympathizers. The Constitutional Court has granted a material review of discriminatory laws and regulations. People who are descendants of the PKI currently have the freedom to be involved in politics and government. People who have lost their citizenship and became exiles in various countries were also given access to return home and become Indonesian citizens again. 


\section{WAYANG IN INDONESIAN CULTURE}

Wayang in Indonesia (Java) has a long history because it has existed since prehistoric times. Many people still love it today and this shows how valuable wayang stories are in Indonesia. This fact is acknowledged internationally through the UNESCO. In 2003, UNESCO declared Indonesian wayang as a world masterpiece in the category of "Masterpiece of Oral and Intangible Heritage of Humanity" (Wibisono; Sudjarwo xxxiv).

Wayang is a traditional perfoming art that is categorized as intangible. It is an interpretation of the epics Mahabharata and Ramayana from India (Padmosoekotjo 14). After its entrance to Java, wayang stories were adapted and edited into the Old Javanese language with additions and adjustments in accordance with the times, thus Javanese wayang stories occurred. Other than in Indonesia, particularly in Java and Bali, wayang stories also exist in various other countries like Malaysia and Thailand. Wayang stories in these countries have much in common with those in Indonesia because they all originated from the Ramayana and Mahabharata epics from India (Pengurus Pramita Jaya).

Wayang stories are very valuable and monumental art products. The superiority of wayang lies in the greatness of the story, the beauty of the delivery, and the firmness of the characters. In addition, the superiority of wayang is also due to philosophical values and moral teachings that are still relevant to the current situation (Mulyono 270). Various wayang stories and their characters are often used as examples of people's behavior and life principles. The existence of wayang is not only an art form for entertainment, but it has also become a part of people's lives.

Wayang is an ancient performance genre that is still regularly and actively consumed by millions of Indonesians today, especially in Java and Bali. There are many regional variations of wayang, but the most easily recognized form is the shadow puppet (wayang kulit) presented behind a lighted screen by a skilled puppeteer (dalang). Although the wayang storylines are mainly taken from the ancient Hindu epics, the Mahabharata, and the Ramayana, wayang performances also provide significant scope for improvisation according to contemporary political events (Keeler 23).

Wayang stories and characters are used as role models, principles of life, a source of values that affect the attitude of life of people who like the story. Circumstances and events in the world of wayang are often seen as symbols that are similar to real-world circumstances and events. Wayang is not only a popular art form, but has become a part of life that is needed by society. Wayang stories carry a mission 
as a means of entertaining as well as educating. As said by Horace, wayang stories function as dulce et utile, sweet and useful, providing enjoyment and benefit.

\section{RELEVANT RESEARCH}

A number of researchers have conducted studies on political facts and wayang in modern Indonesian literary works. In the article entitled "Interogating Indonesian New Order's Narrative of Gestapu: The Leftist Noble and the Indonesian Communist Party in Umar Kayam's Stories," Sarwoto (2017) examines the existence of the Leftist Nobles and the Indonesian Communist Party (PKI) in fiction by Umar Kayam. The results showed that Umar Kayam's fictional texts reflected the failure of the traditional Javanese nobility (priyayi) in revitalizing their role as political leaders in dealing with a corrupt political system. Javanese noblemen who sided with the oppressed by joining the affiliated Communist Party organizations were ostracized and marginalized. Apart from his sympathetic portrayal of those accused of involvement in the G3oS/PKI, Umar Kayam still considers that communism as an ideology is not suitable for the Indonesian people.

In the article entitled "Identities in Exile: Re-membering Identities, Re-membering the Nation in Laksmi Pamuntjak's Amba," Ahmad (2019) examined the people who had been exiled and lost their citizenship identity due to political policies after the G30S/PKI incident described in the novel Amba by Laksmi Pamuntjak. One result of the 1965 purging of Indonesia's leftists when the New Order came to power was the exile. As mentioned earlier, thousands of Indonesians who were abroad at the time suddenly found themselves without citizenship, while tens of thousands were exiled to be imprisoned on Buru island. In Amba, the various modes of exile in Indonesia triggered by 1965 are explored in three characters: Amba, Bhisma, and Samuel. Laksmi Pamuntjak revealed how exile disturbs and delays the formation of identities of different generations of Indonesians, resulting in what is known as an alienated concept of identity.

In the article entitled "Shadow Boxing: Indonesian Writers and the Ramayana in the New Order," Clark (2001) examines the ideas, visions, and styles of a number of Indonesian writers in the New Order era-especially in the last years of the New Order-who chose to process and reinterpret the Ramayana epic from Javanese shadow puppets. The writers with Javanese background deliberately chose the Indonesian language as a communication medium, so they could reach a wider audience. That is one form of their concern for the non-Javanese community in Indonesia. The results showed that the reinterpretation of wayang literaturespecifically the Ramayana epic_could be read as a means of "shadow-boxing" in 
facing the New Order regime. "Shadow-boxing" can be defined as boxing against an imaginary opponent. Extending this metaphor, wayang-based text writers can be considered shadow-boxers; their text is a shadow, and their "imaginary" opponents are Suharto and his New Order regime. Indonesian writers who were critical of the New Order state imagined and acted in their minds the "real" battles that would come in 1997 and 1998, the struggle to overthrow Suharto.

In the article entitled "Shadows on the Page: Javanese Wayang in Contemporary Indonesian Literarture," Downes (2012) examined various wayang constructions in Indonesian novels from the 1980 os to the present by examining the work of three writers, namely YB Mangunwijaya, Putu Wijaya, and Ayu Utami. The focus of the discussion is the complexity of the techniques or ways in which the writers adopt the narrative elements, styles, and wayang themes to the novel discourse. Adaptation is carried out in accordance with the geographical, social, political, and cultural conditions of Indonesia, both during the New Order regime and postauthoritarian Indonesia. Wayang-based literature is a "safe" means of expressing differences of opinion, criticizing the New Order government, and insinuating certain figures. Wayang-based literature can be a means of author involvement with social, historical, and political issues while avoiding the censorship mechanism of the authoritarian regime during the New Order.

In the article entitled "Women Writing Wayang in Post-reform Indonesia: A Comparative Study of Fictional Interventions in Mythology and National History," Downes (2018) examines how Indonesian female writers adapt and make use of wayang elements in writing literary works. Female writers are increasingly recognized in the national literary landscape, but little academic attention has been paid to the involvement of female writers with wayang. Downes further proposed to expand the discussion to include traditional mythology and wayang motifs as alternative sources of cultural authority for female writers in Indonesia. The epic Hindu-Javanese mythology featured in wayang (wayang kulit) performances has long been a source of narrative, style, and thematic materials for Indonesian writers.

\section{DATA SOURCES}

This study aims to describe the integration of political facts or events and wayang in two modern Indonesian novels, namely (a) $A m b a$, a novel by Laksmi Pamuntjak, and (b) Pulang, a novel by Leila S. Chudori. Amba and Pulang were included in the top five nominations of the Khatuliswa Literary Award in 2013, in which Pulang won the award. Amba has also been published in English under the title The Question of Red. The two novels have similarities, namely: (a) raising political 
events in Indonesia, about the 1965 G3oS/PKI and the political life thereafter under the New Order regime (Suharto); (b) transforming the wayang story intensively; and (3) first published almost simultaneously in 2012.

Although with a different story and style, the two novels together took up political issues regarding the G30S/PKI and its impact on political prisoners. Those accused of being involved in the communist movement were detained and imprisoned without trial. The novel Amba raises the background of PKI political prisoners on Buru Island, an island specifically intended for political prisoners. Meanwhile, the novel Pulang is set abroad where exiles stay in places like Paris, France.

Besides being related to political settings and events, the two novels also intensively transformed stories, characters, and wayang symbols. In fact, the title of the novel $A m b a$ actually refers to a wayang character. Likewise, other characters namely Bhisma, Salwa, Ambika, and Ambalika are wayang characters as well. On the other hand, the title Pulang does not illustrate a wayang story. However, it presents elements of the wayang stories. In certain cases, the wayang story in Pulang is more intensive than in Amba. For example, there is a narrative that is intentionally italicized which contains a wayang story. It was deliberately presented as an additional note to emphasize the plot and the characters. Pulang also presents the names of fictional characters that refer to the names of wayang characters. Similar to $A m b a$, there are several chapter subtitles that are named after wayang characters.

\section{POLITICAL SETTINGS AND EVENTS IN AMBA AND PULANG}

In $A m b a$, there are two political events, namely the 1955 election and the 1965 G3oS/PKI. First, the 1955 election set up minor conflicts between husband and wife, Sudarminto and Nunik (Amba's father and mother). Sudarminto chose the PNI (Indonesian National Party), while Nunik admired the PKI (Indonesian Communist Party). This fact does not develop throughout the story. Historical facts show that the PKI came out as one of the top five winners in the 1955 election. The settings of these political events did not have much influence on the whole plot of the novel, but at least showed some signs of disunity due to affiliation with political parties.

Second, the political fact that intensively underlies almost the whole story is the 1965 rebellion. This event can be divided into three stages, namely before, during, and after the rebellion. The event before, among others, appear in the description of an increasingly heated political atmosphere. This was marked by tensions between the people, Muslim youth, and ulama (Muslim scholars) with groups affiliated with 
the PKI, such as Pemuda Rakyat (People's Youth), BTI (Barisan Tani Indonesia, or The Indonesian Peasants Front), and CGMI (Central Gerakan Mahasiswa Indonesia, or The Central Movement of Indonesian Students). The land confiscation by the BTI and Pemuda Rakyat from the landowner farmers led to clashes and even killings everywhere.

The event of the outbreak of the G3oS/PKI rebellion marked by the kidnapping and killing of generals and the power struggle in Jakarta was heard by Bhisma through radio broadcasts. When the PKI began to get cornered, they moved to Central Java and Yogyakarta to fight back. Thus, there was the arrest and elimination of PKI people and various affiliated institutions under the command of the army. Aidit, Chairman of the PKI, who fled to Central Java was captured and immediately shot. Bhisma heard the rumors about the incident from his friends. When Bhisma was at Res Publica University (Ureca) attending a meeting in memory of one of the leftists with Amba, he was arrested. Amba was separated from Bhisma and did not know what happened to him. Sympathizers and all those who were thought to be involved in the Indonesian Communist Party were arrested.

There are two political facts presented in Pulang, namely the events of the G3oS/ PKI rebellion in 1965 and the 1998 student demonstration that led to Suharto's resignation as Indonesian president. Both of these political events are presented continuously in the story so that it appears as a cause and effect. However, there was a change in the main character of the story, from the first generation to the second generation.

The more discussed stage is the after-event, focused on the political exiles abroad who were being chased by the government. Students who studied abroad, especially in communist-leaning countries, had their licenses revoked and their passports made invalid. Finally, they became foreigners who live in other countries and cannot return to Indonesia (Ahmad 69).

The next political fact in Pulang relates to the events of the reform movement in 1998. In order to complete her final assignment at the Sorbonne, Lintang went to Indonesia to make a documentation of people who were victims of the PKI purges. In Jakarta, Lintang was assisted by Alam and friends from LSM Satu Bangsa. Lintang's arrival coincided with the heated events of May 1998 when there were massive student demonstrations demanding Suharto's reform and resignation. In that incident, there were numerous violent events that happened: the shooting of Trisakti students, robbery, arson, and sweeping of citizens of Chinese descent. These incidents ultimately led to the resignation of Suharto as President of the Republic of Indonesia. After the fall of Suharto, political exiles were able to return to their homeland. 


\section{WAYANG TRANSFORMATION IN AMBA AND PULANG}

The transformation of the wayang stories in the novels Amba and Pulang includes two aspects, namely (a) characterization and (b) plot. The transformation of the characterization aspect can be interpreted as the way the author presents the characters of the story. In the context of wayang stories, the names and characterization of the characters are standard and tend to be stereotypical (Nurgiyantoro 207). Referring to this, there are three models of the transformation of wayang characters into the novels. First, transform the name as well as character, namely the names and characters of wayang presented together and inherent in novel characters. Second, the transformation of characterless names, namely the hypogram of the names of the wayang characters into the novel without any standard character descriptions of the wayang characters. Third, nameless character transformation, namely the hypogram of a certain wayang character without being accompanied by the naming of the same character.

Storyline transformation can be interpreted as the way the author presents a novel storyline by referring to the wayang storyline. As with the names and characters, the stories of wayang are also standard. Referring to this, there are two models of transforming wayang lines into novels. First, the hypogram for the love story of the wayang characters, namely the love relationships between the wayang characters in a particular story. Second, the hypogram of the kinship of wayang characters, namely relationships that involve the family lineage of certain wayang characters.

There are two models of character transformation in Amba, namely (a) hypograms for names and characters, and (b) hypograms for characterless names. First, the hypograms for the names and characters in Amba can be found in the three main characters, namely Amba Kinanti (as Amba), Salwa Munir (as Salwa), and Bhisma Rasyad (as Bhisma). The names and the characters in wayang are presented in $A m b a$ in the same description. Second, the hypograms for the characterless names in Amba can be seen in Ambika, Ambalika, and Srikandi. The names of the wayang characters are presented in the novel without being accompanied by the characterization attached to each of them.

There are two models of plot transformation in Amba, namely (a) the love triangle story, and (b) the kinship between characters. First, the hypogram for the love triangle story between the characters Amba, Salwa, and Bhisma. The triangle love story is a hypogram for the love triangle story in the wayang story, although it has gone through an adaptation. Second, the family relationship hypogram appears in the characters Amba, Ambika, and Ambalika. In Amba, the three characters are 
a relative, a brother, and a sister. In the wayang story, the three characters are the daughters of King Kasipura.

Meanwhile in Pulang, there are two models of characterization transformation namely (a) hypograms for nameless characters, and (b) hypograms for characterless names (Nurgiyantoro 213). First, the hypogram for the nameless character appears in the figure of Dimas Surya. Dimas often identifies himself as his favourite wayang characters, namely Bima and Ekalaya. The two wayang characters are used as references to describe his existence and identity. Bima is a metaphor in matters of love, while Ekalaya is a metaphor in matters of love for the motherland even though he is exiled. Second, the hypograms for the characterless names appear in the use of character names, such as Surti, Andini, Rama, Narayana, and Bima. Judging from the character's point of view, it is not clear whether these characters are related to the characters with the same names in the wayang story.

There are two models of plot transformation in Pulang, namely (a) the love triangle story, and (b) the kinship between characters. First, the hypogram for the love triangle story appears in the story of the characters of Dimas Surya and Surti. However, since Dimas was unprepared in terms of money and material things, Surti eventually chose to marry Hananto, Dimas's superior. The love story of Dimas is a metaphor for Bima's love story in the wayang story. Bima really loves Drupadi, but Drupadi prefers to love Arjuna, Bima's younger brother. Second, the hypogram for family relationship occurs in the second generation after Dimas Surya and Surti. Dimas Surya's daughter, Lintang, fell in love with Surti's son, Alam. This kinship story is a metaphor for the love story of Bima and Drupadi. Although Bima did not marry Drupadi, their two children eventually got married. Gatot Kaca, son of Bima, married Pregiwa, daughter of Arjuna.

\section{POLITICAL SETTING INTEGRATION AND WAYANG TRANSFORMATION IN AMBA AND PULANG}

Political facts and wayang stories are neatly woven and complementary to form a coherent story in the two novels. Understanding of literary texts needs to take into account the historical factors and sociocultural life that is the background of the creation of these texts. Understanding the historical setting of political events and the wayang stories present in the two novels will help to understand more fully the meaning of the two novels. Readers who understand the political history of the 1965 uprising and at the same time understand the wayang story will relate their role in understanding the story of the novel. 
The two novels also shared the main theme, namely that there were many people who were victims of arrest by the military because they were accused of being involved with or as PKI sympathizers. Moreover, they did not support the leftwing (communist) ideologies. They were neutral in the midst of a heated political situation and there were tensions between the right-wing and the left-wing politics.

Amba featured a Bhisma character who was a victim: captured without trial, and imprisoned until finally exiled to Buru Island. Pulang mainly featured Dimas, Nugroho, Risjaf, and Tjai, characters who were victims who happened to be abroad. While Bhisma ended up being banished to Buru, Dimas and his friends ended up in Paris as people without citizenship. Bhisma finally died and was buried on Buru Island; Dimas died in Paris, but his body could be repatriated and buried in his homeland. This could have happened because the New Order government had ended with Suharto's resignation as president.

Judging from the dichotomy of the terms "politics in literature" and "literary politics" (Whitebrook 55), what can be seen in both novels refers more to "politics in literature." The presence of a political context, political events, or political history can be found in literary works. There are many important political events presented in both novels, including before, during, and after the event of the rebellion. The events that were mostly presented in the two novels were the setting of the events after the uprising which were centered on the suffering of political victims.

Bhisma, the main character in Amba, was forced to help treat victims from both sides. Bhisma has close friends among people from the CGMI, Gerwani (Gerakan Wanita Indonesia, or Indonesian Women's Movement), and Lekra (Lembaga Kebudayaan Rakyat, or Institute for the People's Culture). It is this friendship with them that ultimately brings consequences to Bhisma so that he is considered an Indonesian Communist Party sympathizer.

The event of the outbreak of the G30S/PKI rebellion marked by the kidnapping and killing of generals and the power struggle in Jakarta was heard by Bhisma through radio broadcasts. When the PKI began to get cornered, they moved to Central Java and Yogyakarta to fight back. Thus, there was the arrest and elimination of PKI people and various affiliated institutions under the command of the army. Aidit, the Chairman of the PKI who fled to Central Java, was captured and immediately shot. Bhisma heard the rumors about the incident from his friends. When Bhisma was at Res Publica University (Ureca) attending a meeting in memory of one of the leftists with Amba, he was arrested. Amba was separated from Bhisma and did not know what happened to him. The arrests were carried out on all those involved, sympathizers, and even those who were considered involved. 
Of the many people arrested, some were imprisoned without trial. For instance, Bhisma was only friends with sympathizers because he helped the injured victims and did not understand what really happened. Without being tried, he was imprisoned in Jakarta, moved to Nusakambangan, and then exiled to Buru Island as a political prisoner. On Buru Island, political prisoners were employed to clear the forest and cultivate it into rice fields under heavy guard by the army. Due to various pressures from the international community, in 1979-1980 they were released and repatriated to their respective regions. However, apparently Bhisma did not come home. It was only in 2006 that his ex-girlfriend, Amba, sought him out on Buru Island and discovered the fact that Bhisma had died. Bhisma became one of the victims of the killings when there was a Christian-Islamic clash in Maluku. It was then discovered that Bhisma left letters containing stories of the sufferings of the people on Buru Island for Amba.

The character of Bhisma is described as a political victim. Bhisma is a doctor who loves his profession, so he is willing to treat anyone in need regardless of political affiliation. He works and helps one another for the sake of humanity. Before the events of the rebellion when the political temperatures were heating up, Bhisma emphatically said: "I know very little about responsibility, but do not ask me about politics" (Chudori 96, 207). He became a political victim when he was arrested for being a sympathizer. The perpetrator of violence is the country through the military (Ardana; Petuguran).

Furthermore, in Pulang a major political event occurred twice which appeared to be related, but at the same time had a contrasting meaning. First, the 1965 political events that followed Suharto's rise as president. Second, student demonstrations and the May 1998 riots that followed the fall of Suharto. The two major events were deliberately intertwined with a sense of "as if there was revenge" of figures of the 1965 political victims, yet of different generations. In the 1965 political events, Dimas and his friends were victims because they were considered communistoriented so that they became outcasts abroad (Ardana). In the 1998 political event, Suharto, who had been in power for 33 years, was an authoritarian "victim" of the demands for reform and was forced to step down.

Dimas and his three friends could not return to Indonesia because they were declared to be involved in the communist movement and were forced to become political exiles abroad and their passports were even revoked. They repeatedly asked for visas but were always refused by the Indonesian embassy. Dimas married Vivienne-a Sorbonne Paris student who took part in the 1968 demonstration and later became a lecturer-and had a daughter, Lintang Utara. Dimas and his three friends established an Indonesian restaurant with an Indonesian menu, yet it was labeled as a PKI restaurant. The families of political prisoners and political 
exiles were also labeled as environmentally unclean and restricted in their mobility (Ahmad 72).

The political victims were mainly four friends: Dimas Surya, Nugroho, Risjaf, and Tjai who were forced to live abroad because they and their families were considered to be involved with or sympathizers of the PKI. Their passports were revoked. They were accused of being involved with no evidence and solely because Hananto's journalist colleague was indeed politically affiliated with the PKI. They had no political affiliation anywhere and did not even know what really happened. Just like Bhisma, they were only victims who experienced the state (military) violence (Ardana; Figueras-Lucero 25).

The political victims of 1965 were the first generation-represented by Dimas, Surti, and others - who in 1998 were old, over 6o years old (Dimas was 68). During the 1998 political events, participants - at the same time movers and coordinatorsin the demonstration were Alam (Surti's son) and Bimo (Nugroho's son). In fact, Lintang (Dimas's daughter) was made by chance to be in Jakarta and witnessed the major event. Therefore, it is as if there were a kind of revenge from the first generation, yet it was done by their children as the second generation.

Various important political events in the context of political history in Indonesia are presented in the novels indirectly. The events are presented through radio broadcasts that are heard by the characters, messages, and advice from others, letters, or stories of a friend $(A m b a)$; through news from abroad, letters, or television broadcasts (Pulang).

Amba dan Bhisma saling melirik. Kata-kata apa yang diharapkan dari mereka? Jam menunjukkan pukul 09.oo. Seperti di bawah komando, mereka serentak berkumpul di dekat radio. Sebuah reportase, mungkin sudah disiarkan senja tadi: suara seorang mayor jendral, Suharto, memenuhi ruang. Tenang tetapi sedikit gemetar seperti menahan marah, ia mengatakan bahwa Gerakan 30 September adalah gerakan "kontrarevolusioner" yang telah melakukan kudeta. Pengumuman ini disusul berita tentang penculikan dan pembunuhan sejumlah perwira tinggi ABRI, dan pernyataan bahwa Angkatan Bersenjata yang akan menindak mereka, dan yang akan menjaga keamanan dan ketertiban dan juga keselamatan Presiden Sukarno. (Pamuntjak 2012, 224-225).

Amba and Bhisma glanced at each other. What words were expected of them? The clock showed 09.00 o'clock. As if under a command, they gathered around the radio. A news report might have been broadcast since this afternoon: the voice of a Major General, Suharto, filled up the room. Calm but slightly trembling restraining anger, he said that the zo September Movement was a "counter-revolutionary" movement that had committed a coup d'état. The announcement was followed by news of the abduction and 
assassination of a number of high commanders of the Indonesian Army, and a statement that the Army would take action, and would keep order and security including the safety of President Sukarno. (Pamuntjak 224-225; translation ours)

Mas Dimas,

[...]

Mbak Surti yang sejak peristiwa 65 terus-menerus diinterogasi di Guntur, kini juga dibawa, Mas. Dia tidak mau meninggalkan Kenanga, Bulan, dan Alam ... Sekali lagi Ibu menekankan sebaiknya Mas Dimas tetap di Eropa saja. Kami sudah merasa lebih tenang di Jakarta. Perburuan semakin mengganas, bukan hanya mereka yang dianggap komunis, atau ramah kepada PKI. Kini keluarga atau sanak famili pun kena ciduk. Ada yang dikembalikan, ada yang hilang begitu saja, ada yang dihanyutkan ke sungai. Kebetulan Ibu dan aku hanya sempat dipanggil beberapa kali ke Guntur, tetapi kami dipebolehkan pulang setelah seharian menjawab pertanyaan yang itu-itu saja.

Adikmu, Aji Surya

(Chudori 19)

Dear Brother Dimas,

$[\ldots]$

Older sister Surti, who has since 65 been continuously interrogated in Guntur, is now taken too, Brother. She does not want to leave Kenanga, Bulan, and Alam behind ... Once more Mother stresses that it is better for you to remain in Europe. We now feel calmer in Jakarta. The chase is fiercer, not only those who are accused as communists or are friendly to PKI. Now family and relatives are taken too. Some are returned, others disappear just like that, and still, others are drowned into the river. Mother and I are accidentally sent to Guntur a number of times, but we are allowed to go home after all day long answering those same questions.

Your younger brother,

Aji Surya

(Chudori 19; translation ours)

The dark political events of 1965 are now responded to differently by later generations. For this generation, those political events have become a history of the past or even become stories that are similar to fiction. Nevertheless, not a few people clearly question the event again. Moreover, it was a fact that there really was the abduction and killing of the generals. The generals are victims of the atrocities of communism. However, the repressive actions of the authorities through arrest, interrogation, torture, even murder, and imprisonment of many people who were actually not involved had also resulted in new political "victims" (Ardana; Petuguran). There were families and children who were still little, infants, 
or even unborn when it happened. Why were they also considered guilty? That is what the two novels want to reveal and question, especially in Pulang. This novel exists to question the repressive actions of the authorities which are considered excessive (Downes 115).

During its time in power, the New Order government made an "official national history of Indonesia" which was used as learning materials at various levels of education. However, not a few historians are questioning the objectivity and validity of that event. In fact, this "official history" version of the New Order government is viewed as a fictional story. Since it has been socialized insensitively and repetitively, even forced to be promoted to the society and the world of education, the truth of "official history" that is considered more fictional was as if transformed into factual truth (Petuguran).

After the fall of Suharto, the information flow became increasingly open, so the information about what actually happened in the dark year of 1965 and the purge of the actual and alleged PKI members became public. At last, people can search for other information sources that are more objective, and they can now dare to express opinions. Information about the G30S/PKI rebellion which was closed during the New Oreder era is also mentioned in Pulang as "historical malpractice." The young children of the second generation can see the history of the past more clearly as there is a relatively sufficient grace period of about 30 years.

Aku kalah. Kalau sudah menyulitkan orang tua, itu memang dosa terbesar. Yu Kenanga keluar dari kamarku sambil masih terus menggerutu. Heran aku, betapa banyaknya persediaan gerutuan kakakku itu. Aku menghampiri Bimo yang masih menggambar: MALPRAKTEK SEJARAH dengan sebuah tangan yang mengepal dan meninju dua kata itu menjadi kumpulan huruf yang terurai berkeping-keping.

Saat kuliah, aku bertekad untuk melihat sejarah dengan lebih jernih daripada sekadar menjadi 'anak Bapak'. Literatur yang tersedia sangat terbatas. Sejarah resmi sudah jelas hanya satu pihak. Aku juga tak mau melihat segalanya dari sisi defensif. Dari perbincangan informal dengan sejarawan yang diam-diam mengakui ada kepentingan Orde Baru untuk mengukuhkan kekuasaan, persoalannya ada pada konflik di kalangan elit. (Chudori 296; translation ours).

I lost. When making things hard for your parents, it is truly a big sin. Older sister Kenanga came out of my room while continually grumbling. I wonder how she has that large stock of grumbles. I approached Bimo who was still drawing: HISTORICAL MALPRACTICE with a fist closed and punching the two words to become a bunch of letters scattered everywhere.

When I was in college, I was determined to look at history more clearly than just becoming a 'father's son. Available references were very limited. Official history was 
clearly only one side. Neither did I want to look at everything from the defensive side. From informal talks with historians who silently admitted there were interests of the New Order to fortify their power, the problem lies in the conflict among the elites (Chudori 296).

The novel's characters, which are transformations of characters in the wayang story, serve as a means of revealing and reinterpreting the facts of political history (Basuki 70). In the process of storytelling and reinterpretation, stories and references to wayang are coherently intertwined with other story elements. If a political event is presented as the setting, the wayang story is used as a reference to character development, plot, and cultural reference. Viewed from the standpoint of the theory of intertextuality, it shows that there is an element of retrieval, yet deliberately adapted to modern life (Lunkova). However, viewed from the side of the semiotic entity, it clearly demonstrates the suitability (Lemaster).

\section{CONCLUSION}

The presence of political aspects and wayang stories in modern Indonesian literature is not a new discovery. Yet what this study suggests is that historical facts and wayang stories as integrated in Amba and Pulang can bring into light how political events such as the G30S/PKI uprising of 1965 created an impact on people's sociopolitical life. Moreover, references of political events and wayang stories are intertextual issues that are linked by the existence of semiotic entities between the reference source and the one that it refers to. If a political event is presented as the historical setting, the wayang story acts as a reference to character development, plot, and cultural reference.

The references to the names of the characters and the wayang storylines in the two novels appear to be functional as they influence other elements of the story. The characters and storylines are hypograms of the wayang stories. Wayangbased literature is a safe means of expressing differences of opinion, criticizing the government, and insinuating deviant behavior of a certain figure. The integration of political facts and wayang stories in a novel is a medium for an author to convey critical thinking and alternative views on understanding the Indonesian national history.

Wayang is a source of inspiration for creation that can be adapted and adjusted to various forms, such as comics, television drama series, and novels. Through these various forms, wayang can become a medium for disseminating views and criticism

of Indonesian culture, politics, and society today. As a source of inspiration and 
literary motifs, wayang offers a familiar outline of characters and themes that are both dynamic and contextual. Telling stories using wayang symbols can be a way to avoid censorship. On the other hand, through wayang, the authors can convey thoughts about historical construction, tradition, and culture from a point of view different from that of the government or the state.

Wayang-based literature can be a "safe" means of expressing differences of opinion, breaking through stagnant governance, mocking influential figures, and engaging in social, historical, and political issues. By modifying and adapting traditional wayang stories in a subtle way, the author is able to challenge the dominant elite conception of societal cultural concepts and behavior. The way in which writers reflect on wayang through literary works can reveal important insights into Indonesia's geographical, social, and cultural politics, both in the New Order and post-authoritarian Indonesia. This becomes important considering that it is very possible that new informal authorities will emerge or even the old authoritarianism pattern will survive in a way that spreads and mingles with something that is considered new. 


\section{Acknowledgments}

We wish to thank the anonymous reviewers for their comments and suggestions, all of which have helped us improve this paper. 


\section{Works Cited}

Ahmad, Siti Nuraishad. "Identities in Exile: Re-membering Identities, Re-membering the Nation in Laksmi Pamuntjak's Amba." Kritika Kultura, no. 33/34, 2019/2020, pp. 65-87.

Amnesty International. Indonesia: An Amnesty International Report. Amnesty International Publications, 1977. https://www.amnesty.org/download/ Documents/20400o/asa210221977en.pdf.

Anwar, Rosihan. Sukarno, Tentara, PKI, Segitiga Kekuasaan sebelum Prahara Politik 1961-1965. Yayasan Obor, 2006.

Ardana, Alwi A. "Amba Ingin Pulang tapi Takut Jadi Komunis." IndoProgres, 5 Sept. 2013, http://indoprogress.com/2013/o9/amba-ingin-pulang-tapi-takut-jadi-komunis/. Accessed 1o Feb. 2019.

Basuki, Ribut. "Panakawan's Discourse of Power in Javanese Shadow Puppet during the New Order Regime: From Traditional Perspective to New Historicism." K@ta, vol. 8, no. 1, 2006, pp. 68-88.

Chudori, Laila S. Pulang: Sebuah Novel [Return: A Novel]. Kepustakaan Populer Gramedia, 2012.

Clark, Marshall. "Shadow Boxing: Indonesian Writers and the Ramayana in the New Order." Indonesia, vol. 72, 2001, pp. 159-187.

Cribb, Robert. "Genocide in Indonesia, 1965-1966." Journal of Genocide Research, vol. 3, no. 3, 2001, pp. 219-239.

Downes, Meghan. "Shadow on the Page: Javanese Wayang in Contemporary Indonesian Literature." RIMA: Review of Indonesian and Malaysian Affairs, vol. 46, no. 1, 2012, $127-149$.

-.. "Women Writing Wayang in Post-reform Indonesia: A Comparative Study of Fictional Interventions in Mythology and National History." The Southeast Asian Woman Writes Back: Gender, Identity and Nation in the Literatures of Brunei Darussalam, Malaysia, Singapore, Indonesia and the Philippines, edited by Grace V.S. Chin and Kathrina Mohd Daud, Springer, 2018, pp. 107-127.

Eickhof, Martijn, Gerry van Klinken, and Geoffrey Robinson. "1965 Today: Living with the Indonesian Massacres." Journal of Genocide Research, vol. 19, no. 4, 2019, pp. 449-464.

Eilders, Christiane, and Cordula Nitsche. "Politics in Fictional Entertainment: an Emperical Classification of Movies and TV Series." International Journal of Communication. vol. 9, 2015, pp. 1563-1587.

Figueras-Lucero, Adelaida A. "The Wayang Kulit as the Narrative Framework of Pramudya Ananta Tur's Perburuan (The Fugitive)." Journal of English Studies and Comparative Literature, vol. 2, no. 1, 1997, pp. 19-34.

Hamid, Mohsin. "Does Fiction Have the Power to Sway Politics?" New York Times, 22 Feb. 2015. https://www.nytimes. com/2015/02/22/books/review/does-fiction-have-thepower-to-sway-politics.html. Accessed 23 Mar. 2019. 
Janoory, Lajiman, Mohammad Sidik Ariffin, and Mazura Mastura Muhammad. "A Reimagining of History Based on the Novel The Harmony Silk Factory by Tash Aw." 3 L: Language, Linguistics, Literature: The Southeast Asian Journal of English Language Studies, vol. 22, no. 2, 2016, pp. 187-198.

Junus, Umar. Fiksyen dan Sejarah, Suatu Dialog. Dewan Bahasa dan Pustaka, 2006.

Keeler, Ward. Javanese Shadow Plays, Javanese Selves. Princeton UP, 1987.

Lemaster, Tracy. "What is Intertextuality?" Digital Imaging: The Ohio State University, Art \& Technology, 2014. https://250oart.files.wordpress.com/2014/o1/what_is_ intertextuality.pdf. Accessed 24 Mar. 2019.

Leong, Kar-Yen. "Filling in the Gaps: Remembering the Killing in Indonesia." Kritika Kultura, no. 33/34, 2019/2020, pp. 729-760.

Lunkova, Larisa N. “The Patterns of Intertextuality." International Reserach Journal, Oct. 2012, https://research-journal.org/en/philology/the-patterns-of-intertextuality/. Accessed 25 Mar. 2019.

Mulyono, Sri. Wayang, Asal-Usul, Filsafat, dan Masa Depannya. CV Haji Masagung, 1989.

Nurgiyantoro, Burhan. "Transformasi Cerita Wayang dalam Novel Amba dan Pulang." Litera Jurnal Penelitian Bahasa, Sastra, dan Pengajarannya, vol. 15, no. 2, 2016, pp. 201-216.

Padmosoekotjo, Sitam. Silsilah Wayang Purwa Mawa Carita, Jilid I. Citra Jaya Murti, 1993. Pamuntjak, Laksmi. Amba: Sebuah Novel [Amba: A Novel]. Gramedia, 2012.

Pausacker, Helen. "President as Punakawan: Portrayal of National Leaders as ClownServants in Central Javanese Wayang." Journal of Southeast Asian Studies, vol. 35, no. 2, June 2004, pp. 213-233.

Pengurus Paramita Jaya. "Kajian Wayang: Sejarah Wayang Kulit." Paramita Jaya, 9 Aug. 2015, https://amidajaya.wordpress.com/advokasi/pendidikan-dan-latihan/diklat_ konservasi_tekstil/kajian-wayang/. Accessed 24 Mar. 2019.

Petuguran, Rahmat. "Perang Fakta dalam Fiksi: antara Pengkhianatan G3oS/PKI dan Lubang Buaya." Portalsemarang, 14 Feb. 2014, http://portalsemarang.com/perangfakta-dalam-fiksi-antara-pengkhianatan-g3ospki-dan-lubang-buaya/. Accessed 15 Jan. 2019.

Rancière, Jacques. "The Politics of Literature." SubStance. vol. 33, no. 1, 2004, pp. 10-25.

Roosa, John. Pretext For Mass Murder: The September zoth Movement and Suharto's Coup D'etat In Indonesia. U of Wisconsin P, 2006.

Said, Salim. "Dari Permainan Segi Tiga ke Sebuah Prahara, Sebuah Pengantar." Dalam Rosihan Anwar. Sukarno, Tentara, PKI, Segitiga Kekuasaan sebelum Prahara Politik 1961-1965. Yayasan Obor, 2006, pp. X-xiv.

Sarwoto, Paulus. "Interogating Indonesian New Order's Narrative of Gestapu: The Leftist Noble and the Indonesian Communist Party in Umar Kayam's Stories." Kritika Kultura, no. 29, 2017, pp. 101-125.

Sayed, Asma. "Literature as Politics." Canadian Literature: A Quarterly of Criticism and Review, no. 228-229, 2016, pp. 251-252. https://canlit.ca/article/literature-as-politics/. 
Sudjarwo, Heru S. Sumari, dan Wiyono, Untung. Rupa and Karakter Wayang Purwa. Kakilangit Kencana Prenada Media Group, 2010.

Sayuti, Suminto A. Berkenalan dengan Prosa Fiksi. Penerbit Gama Media, 2004.

Whitebrook, Maureen. "Politics and Literature." Politics, vol. 15, no. 1, 1995, pp. 55-62.

Wibisono, Singgih. "Wayang, Karya Agung Dunia." Sastra Indonesia, 14 Dec. 2009. http:// sastra-indonesia.com/2009/12/wayang-karya-agung-dunia/. Accessed 24 Mar. 2019. 